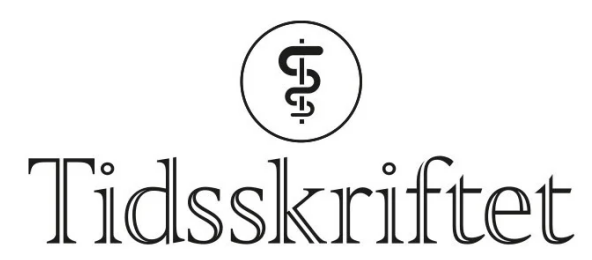

DEN NORSKE LEGEFORENING

\title{
Kan luftforurensning øke risikoen for covid-19?
}

DEBATT

\section{JØRN A. HOLME}

Jørn A. Holme er forskningssjef ved Avdeling for miljø og helse ved Folkehelseinstituttet. Forfatteren har fylt ut ICMJE-skjemaet og oppgir ingen interessekonflikter.

\section{MARIT LÅG}

Marit Låg er seniorforsker og rådgiver ved Avdeling for miljø og helse ved Folkehelseinstituttet. Forfatteren har fylt ut ICMJE-skjemaet og oppgir ingen interessekonflikter.

\section{JOHAN ØVREVIK}

Johan Øvrevik er forskningssjef ved Avdeling for miljø og helse ved Folkehelseinstituttet og professor II ved Institutt for biovitenskap ved Universitetet i Oslo.

Forfatteren har fylt ut ICMJE-skjemaet og oppgir ingen interessekonflikter.

\section{KARAN GOLESTANI}

karan.golestani@fhi.no

Karan Golestani er spesialist i infeksjonssykdommer og overlege ved Avdeling for smittevern og beredskap ved Folkehelseinstituttet.

Forfatteren har fylt ut ICMJE-skjemaet og oppgir ingen interessekonflikter.

\section{Luftforurensning er en velkjent risikofaktor for ulike sykdommer, og kanskje også for covid-19.}

Globalt er luftforurensning en av våre viktigste miljørelaterte helserisikofaktorer, og medvirkende årsak til kardiovaskulære sykdommer, nedsatt lungeutvikling, redusert lungefunksjon, kols og $ø$ kt forekomst og forverring av astma (1). Små forbrenningspartikler i svevestøv ser ut til å gi mest helseskader, men gasser og større veistøvpartikler bidrar også.

Luftforurensning gir sannsynligvis også økt risiko for akutte infeksjoner i øvre og nedre luftveier $(\underline{2}, 3)$.

\section{$\emptyset \mathrm{kt}$ risiko for covid-19}

Det er i flere studier rapportert om en sammenheng mellom mengde av luftforurensningspartikler og forekomst og dødelighet av covid-19 (4-7.). 
Man bør imidlertid være litt forsiktig med tolkning av slike sammenhenger. Resultatene fra en nylig publisert studie indikerer at sammenhengene kan skyldes konfunderende

faktorer ( $\underline{8})$.

En rekke virus og bakterier fra aerosoler og svevestøv er identifisert ved hjelp av DNA- og RNA-sekvensering, og også SARS-CoV-2-RNA er funnet på svevepartikler (9.). På grunn av uttynningseffekt er det imidlertid usannsynlig at svevestøv i uteluft skulle utgjøre en reell transmisjonsmåte.

\section{$\emptyset \mathrm{kt}$ mottagelighet for SARS-CoV-2}

Kronisk eksponering for luftforurensningspartikler og forhøyede nivåer av nitrogendioksid $\left(\mathrm{NO}_{2}\right)$ er assosiert med høyt blodtrykk, hjerte- og karsykdom, kronisk lungesykdom og diabetes, som alle er velkjente risikofaktorer for et alvorlig covid-19-forløp (므).

SARS-CoV-2 bruker den cellulære reseptoren ACE2 (angiotensinkonverterende enzym 2) til viral inngang. Den finnes på type II-pneumocytter i bronkiale grener i lungene, men også i myokard, nyrer og vaskulære endotelceller (11). Eksponering for sigarettrøyk er vist å kunne oppregulere ACE2-reseptoren. Tilsvarende er det vist at inhalasjon av luftforurensningspartikler øker nivået av ACE2-reseptoren i rotter og humane epitelceller

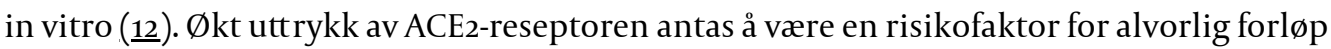
ved covid-19 (11).

«Det er i flere studier rapportert om en sammenheng mellom mengde av luftforurensningspartikler og forekomst og dødelighet av covid-19"

Luftforurensning kan også føre til økt mottagelighet for sykdom i luftveiene via andre mekanismer. Det er vist at luftforurensning gir proinflammatoriske responser, reduserer funksjonaliteten av lungeepitelbarrierer, nedsetter mukociliær transport og fører til immundefekter inkludert redusert evne til å gjenkjenne og fjerne patogener (므). Luftforurensning kan føre til en mer allergirettet Th2-respons (T-hjelpercelle 2) og forsinket vevsrestitusjon. Ubalanse i Th2- versus Th1-respons antas å være en immunologisk faktor som faller sammen med alvorligere sykdom ved sars, mers og covid-19 $(\underline{2}, 3,13)$.

Protrombotisk status er sentral i patogenesen og det kliniske bildet ved covid-19, og det finnes indikasjoner for at kronisk eksponering for luftforurensning kan føre til en prokoagulativ status (14).

Samlet sett ser det ut til at luftforurensning kan være medvirkende årsak til økt forekomst og risiko for covid-19 i de mest forurensede byene.

\section{LITTERATUR}

1. Landrigan PJ, Fuller R, Acosta NJR et al. The Lancet Commission on pollution and health. Lancet 2018; 391: 462-512. [PubMed][CrossRef]

2. Horne BD, Joy EA, Hofmann MG et al. Short-term elevation of fine particulate matter air pollution and acute lower respiratory infection. Am J Respir Crit Care Med 2018; 198: 759-66. [PubMed] [CrossRef]

3. Brugha R, Grigg J. Urban air pollution and respiratory infections. Paediatr Respir Rev 2014; 15: 1949. [PubMed]

4. Fattorini D, Regoli F. Role of the chronic air pollution levels in the Covid-19 outbreak risk in Italy. Environ Pollut 2020; 264: 114732. [PubMed][CrossRef]

5. Wu X, Nethery RC, Sabath BM et al. Exposure to air pollution and COVID-19 mortality in the United States: A nationwide cross-sectional study. medRxiv 2020; 2020.04.05.20054502. [PubMed][CrossRef] 
6. Bashir MF, Ma BJ, Bilal et al. Correlation between environmental pollution indicators and COVID19 pandemic: A brief study in Californian context. Environ Res 2020; 187: 109652. [PubMed][CrossRef]

7. Magazzino C, Mele M, Schneider N. The relationship between air pollution and COVID-19-related deaths: An application to three French cities. Appl Energy 2020; 279: 115835. [PubMed][CrossRef]

8. Cox LA, Popken DA. Should air pollution health effects assumptions be tested? Fine particulate matter and COVID-19 mortality as an example Global epidemiology 2020; 2: 100033. [CrossRef]

9. Setti L, Passarini F, De Gennaro G et al. Searching for SARS-COV-2 on particulate matter: A possible early indicator of COVID-19 epidemic recurrence. Int J Environ Res Public Health 2020; 17: 2986. [PubMed][CrossRef]

10. Ambient air pollution: a global assesment of exposure and burden of disease. Geneve: World Health Organization, 2016. https://www.who.int/phe/publications/air-pollution-globalassessment/en/ Lest 11.11.2020.

11. Chung MK, Karnik S, Saef J et al. SARS-CoV-2 and ACE2: The biology and clinical data settling the ARB and ACEI controversy. EBioMedicine 2020; 58: 102907. [PubMed][CrossRef]

12. Tung NT, Cheng PC, Chi KH et al. Particulate matter and SARS-CoV-2: A possible model of COVID-19 transmission. Sci Total Environ 2021; 750: 141532. [PubMed][CrossRef]

13. Zhang YY, Li BR, Ning BT. The comparative immunological characteristics of SARS-CoV, MERS-CoV, and SARS-CoV-2 coronavirus infections. Front Immunol 2020; 11: 2033. [PubMed][CrossRef]

14. Robertson S, Miller MR. Ambient air pollution and thrombosis. Part Fibre Toxicol 2018; 15: 1. [PubMed][CrossRef]

Publisert: 14. desember 2020. Tidsskr Nor Legeforen. DOI: 10.4045/tidsskr.20.0843

Mottatt 20.10.2020, godkjent 11.11.2020.

(C) Tidsskrift for Den norske legeforening 2023. Lastet ned fra tidsskriftet.no 26. april 2023. 